DOI: $10.19195 / 2082-8322.8 .2$

Jerzy Olek

SWPS Uniwersytet Humanistycznospołeczny

Wrocław

\title{
Reprezentacja zawarta w odbiciu
}

Pomimo że oko jest dalece niedoskonałym narządem, dostrzegamy obiekty oddalone od Ziemi o setki tysięcy lat świetlnych. Są to jednak wyizolowane z pełni kosmicznego kontekstu pojedyncze doznania. Całości nie ogarniemy nigdy, choćby dlatego, że ze światła znajdującego się we wszechświecie przyjmujemy zaledwie jedną tysięczną procenta. To bardzo mało.

Odnosząc rzecz do sztuki i jej egzystowania, przyjdzie nam stwierdzić, iż ona również lokuje się w wąskim zakresie możliwej skali, spełniając się gdzieś pośrodku pomiędzy nieskończonością świata nieprzekraczalnie tajemniczego a zagadkowością jego ciągle niepoznawalnych mikrostruktur. Współcześni artyści coraz odważniej sięgają do nanoskali, nadal nie próbując niczego tworzyć w kosmosie. A przecież rysuje się jakieś wyjście z tej sytuacji. W niedającej się jeszcze przewidzieć przyszłości podejmowane z pobudek twórczych wyprawy w stronę niewyobrażalnie odległych zakątków wszechświata z jednej strony, zaś z drugiej - superprecyzyjne wypady na bezdroża materii poziomu kwantowego uwolnią Ziemię od kłopotliwych efektów nadprodukcji sztuki, której gwałtownie rosnąca ilość jest nie do pomieszczenia w muzealnych sarkofagach, mimo iż stale ich przybywa. Już dzisiaj łatwo wyobrazić sobie ekspedycje kosmiczne, które na orbity wokół Jowisza i Saturna, a w przyszłości jeszcze dalszych planet, nawet znajdujących się w najodleglejszych galaktykach, zabiorą pokaźną ilość obrazów, rzeźb i grafik. Na razie jednak NASA woli wysyłać ludziki LEGO, jak to zrobiła, doposażając Juno - sztucznego satelitę największej planety układu słonecznego - figurkami Galileusza, Jowisza i Junony, co zresztą nie rozwiązuje problemu, jako że po niedługim czasie pracy zamontowanej na sondzie aparatury wyrafinowanie techniczny statek i tak spłonie. Trudniej wyobrazić sobie miniaturyzację twórczości tak radykalną, by powstające w jej rezultacie twory 
zbliżały się do wielkości bozonu Higgsa - teoretycznie przewidzianej przed pół wiekiem i w końcu odkrytej cząsteczki, która pozwoliła zaistnieć materii w prapoczątkach wszechświata. Na drodze minimalizacji trójwymiarowych obiektów osiągnięto już bardzo wiele. Długą tradycję ma malarstwo japońskie na ziarnkach ryżu; w Tokio wydrukowano ilustrowaną książkę Shiki no Kusabana o 22 stronach 0,75 mm długości każda, na których szerokość liter nie przekracza $0,01 \mathrm{~mm}$; w ostatnim czasie powstały rzeźby w mikroskopijnej skali.

Artystą uprawiającym Nannosculpture Needle Eye Sized Art jest Jonty Hurwitz, który jedną ze swoich figurek - postać tańczącej kobiety - umieścił na ludzkim włosie, w tym zestawieniu sprawiającym wrażenie grubego walca. Wielkość takiej rzeźby nie przekracza 100 mikronów. W swojej pracy Hurwitz posługuje się mikroskopem elektronowym i drukarką 3D, wykorzystując technologię dwufotonowej litografii. Czym są mini minirzeźby? Obiektami, które pojawiły się w nienasyconym gabinecie osobliwości, w łakomym panopticum, gdzie znudzeni widzowie oczekują coraz to nowszych atrakcji. Wrażenie robią ogromne. Skulona postać serfująca po ludzkiej rzęsie, słoń przemierzający puste terytorium pokryte głębokimi bruzdami, które w rzeczywistości są odciskiem palca. Niezwykłe w twórczości Hurwitza jest zaskakujące operowanie skalą, pozwalające na intrygujące zderzanie struktur mikroi makroświata. Nanorzeźby świetnie też będą nadawały się do zasiedlania statków kosmicznych, z których zawsze mogą się przesiąść na gromady protonów lub neutrin i odlecieć w nieznane. Hurwitz mówi o sobie jako archetypie artysty naukowca obiecująca dwuosobowość.

Technika dwufotonowej litografii stosowana w procesie druku trójwymiarowych obiektów jest obecnie niezwykle precyzyjna i szybka, co jest zasługą naukowców z Uniwersytetu Technicznego w Wiedniu. Znakomicie nadaje się do wykorzystania w przemyśle i medycynie. Płynną żywicę utwardza laser, którego biegiem sterują szybko poruszające się lustra. Urządzenie skonstruowane na austriackiej uczelni zapewnia drukowi 3D w nanoskali prędkość wykonania rzędu $5 \mathrm{~m}$ na sekundę. Łatwo wyobrazić sobie masową produkcję niewidocznych gołym okiem dziełek wielkości pyłu. Nie byłoby problemu z gromadzeniem — być może artystycznych — obiektów we własnym domu: wielka kolekcja mieściłaby się w małym pudełku.

Nie tylko teoretycznie jest to możliwe. Skuteczne ingerowanie w materię z dokładnością nanometrową jest absolutnie realne. Podany tu przykład jest tego najlepszym dowodem. Żywica utwardza się w trakcie naświetlania laserem tylko wtedy, kiedy pobudzające go cząsteczki pochłoną dwa fotony jednocześnie, co ma miejsce wyłącznie w środku laserowego promienia. Zjawisko godne uwagi samo w sobie. Problem $\mathrm{w}$ tym, że trudno je zobaczyć nieuzbrojonym w specjalistyczną aparaturę okiem.

Ale czy wszystko musi dawać satysfakcję estetyczną w bezpośrednim oglądzie? Czy nie wystarczy świadomość, że spektakularnie jest je w stanie odsłonić odpowiednia maszyneria? Byłby to zatem rodzaj konceptualizmu w mikroskali, gotowego jednak na dostępne zmysłom potwierdzenie. Jakąż zapewniłoby to oszczędność prze- 
strzeni artystom praktykującym klasyczne formy wypowiedzi, gdyby tworzyli rzeźby wielkości tysięcznych części milimetra sześciennego i fotonowym pędzlem malowali obrazy o podobnych rozmiarach.

Fotonów jest pod dostatkiem. Pozostaje uczynić z nich sprawne narzędzie artystycznej kreacji, w której już nie będzie chodziło o wytwarzanie reprezentacji czegokolwiek znanego, lecz o generowanie wyglądów wcześniej niespotykanych, które z braku lepszych określeń nazywane będą świetlną abstrakcją. Zjawiska pojawiające się w ziemskiej atmosferze, takie jak tęcze, zorze czy fatamorgany, dostępne z powodu wielkiej ich skali, znane są od niepamiętnych czasów. Ciągle natomiast nie są osiągalne dla ogółu efekty krótkotrwałych zdarzeń, przebiegających w małej skali. A musi ich być we wszechświecie, lecz także w najbliższym otoczeniu ziemskiego globu niepoliczalna ilość, zważywszy na to, ile znajduje się w nim materiału. Wszak wszechświat składa się głównie z fotonów. Jak ustalili astrofizycy, na każdy proton przypada w nim około dwa miliardy fotonów. Działający w kosmosie mechanizm skrótowo opisuje John D. Barrow:

W efekcie anihilacji protonu i antyprotonu powstają dwa fotony. Widzimy więc, że wszechświat taki jak nasz, w którym na jeden proton przypada około dwu miliardów fotonów, musiał powstać z jakiegoś gorącego i gęstego stanu materii, w którym na każdy miliard antyprotonów przypadało średnio miliard i jeden protonów. Miliard protonów zderzyło się z miliardem antyprotonów, wytwarzając dwa miliardy fotonów na każdy pozostały proton ${ }^{1}$.

Oznacza to, że artystycznego "paliwa” długo nie zabraknie.

Nie pretendując - przynajmniej na razie - do miana kreatorów w wymiarze kosmicznym, artyści zafascynowani nieodkrytą do końca potencją nowych mediów zadowalają się tym, co udaje się wywołać i pokazać w obrębie atmosfery ziemskiej, starając się w niej tworzyć widowiskowe spektakle.

Jednym z pionierów był Stanisław Ostoja-Kotkowski, który pod niebem Australii aranżował niezwykłe projekcje - laserowe koncerty. Wykonał też kinetyczny fresk słoneczny Solaris. Były to sztucznie stworzone złudy, które sprawiały wrażenie niematerialnych, choć ponad wszelką wątpliwość istniały wizualnie. Widziane było coś, czego nie dawało się potwierdzić dotknięciem ręki. Zupełnie jak w holografii. Przez obraz wymodelowany laserem można przecież bezkolizyjnie przejść. Ale czy hologram jest obrazem? Jean Baudrillard twierdzi, że nie. Co więcej, uważa, iż w jego wypadku przestrzeń staje się nierzeczywista. Podaje ponadto w wątpliwość skuteczność iluzyjną tego rodzaju projekcji, twierdząc, że:

Hologram jest [...] pozbawiony[m] inteligencji iluzji trompe-loeil, której przysługiwała zdolność uwodzenia, działania — zgodnie z zasadą pozoru — nieodmiennie za pomocą aluzji i elipsy obecności. Przeciwnie, pogrąża się on w fascynacji dotarcia bezpośrednio na stronę sobowtóra ${ }^{2}$.

1 J.D. Barrow, Wszechświat a sztuka, przeł. J. Skolimowski, Warszawa 1999, s. 179.

2 J. Baudrillard, Symulakry i symulacja, przeł. S. Królak, Warszawa 2005, s. 132. 
Istotnie, hologram jest kopią przedmiotu zmapowaną promieniem lasera, jego świetlną powtórką, bliźniakiem zbudowanym z samych fotonów. Nie wywołuje iluzji, albowiem sam jest iluzją, omamem, który by być czytelnym dla zmysłu wzroku, niekoniecznie potrzebuje wsparcia realnego obiektu, ponieważ równie dobrze może przedstawiać sztucznie wygenerowaną irrealność. Hologram, charakteryzujący się tym, że każda jego część zawiera pełną informację, stanowiący nie tyle jej kondensat, ile dokładne powtórzenie, doskonale nadaje się do symbolizowania nietypowych koncepcji z zakresu filozofii fizyki.

Posłużył się nim David Bohm, traktując hologram jako znak nowego obrazu świata. Według jego koncepcji mechanika kwantowa posiada holistyczne umocowanie, co oznacza, że nie może być oddzielona od doświadczanej całości uwikłanej w ustawiczną zmienność. Motywując adekwatność modelową hologramu do głoszonej idei, badacz stwierdzał:

Pole kwantowe zawiera informacje na temat całego otoczenia i całej przeszłości i ta informacja reguluje obecną aktywność elektronu w ten sam sposób, w jaki informacja o całej przeszłości i całym otoczeniu reguluje za pośrednictwem świadomości naszą własną, ludzką aktywność ${ }^{3}$.

Omówioną w książce Ukryty porządek ideę określił nazwą Holo-Movement. Fotograficzny zapis dwufalowego obrazu interferencyjnego, dający dwa niezależne od siebie obrazy przestrzenne 3D, czyli hologram, wyróżnia się spośród innych rodzajów obrazu tym, że rejestruje wybrany fragment rzeczywistości bez pośrednictwa dodatkowych urządzeń, takich, jakie przykładowo stosuje się w tradycyjnej fotografii, czyniąc ukazywaną przestrzeń nierzeczywistą. Projekcja holograficzna odbywa się przed płytką, na której utrwalony został emitowany przez nią widok. Sytuuje to widza w bezpośredniej bliskości generowanego przez światło widziadła. W wypadku anamorfozy jest inaczej. Jeżeli na cylindrycznej powierzchni lustrzanej ma się pojawić w odbiciu zrozumiała reprezentacja, wokół cylindra musi znajdować się odpowiednio skomponowany obraz lub właściwie wymodelowana forma przestrzenna, aby na odbijającym otoczenie walcu refleksyjnie pojawiło się pożądane złudzenie.

Kiedy staje się przed anamorficznym obiektem — obrazem lub rzeźbą — oraz odbijającym jego wizualną zawartość lustrzanym walcem, stożkiem bądź kulą, pojawia się $\mathrm{w}$ procesie odbioru nieunikniona konstatacja, iż ważniejsze od dopatrywania się w widzianej scenie znaczeniowej zbieżności całego przedstawienia jest akceptowanie rozbieżności zastosowanych konwencji obrazowania. Nie temat wiedzie tu prym, lecz sposób jego ujęcia. Anamorfoza zdaje się łączyć w sobie trudne do pogodzenia przeciwieństwa - niekonwencjonalna konwergencja, rysująca się w tym wypadku jako podobieństwo obrazu i jego odbicia zarazem, jest ich optyczną dywergencją. Zasadność rozpatrywania wzajemnego podobieństwa obrazu i jego kopii powstającej w refleksyjnym odbiciu ma swoje umocowanie w ich ścisłej zależności geome-

${ }^{3}$ R. Weber, Poszukiwanie jedności. Nauka i mistyka, przeł. K. Środa, Warszawa 1990, s. 44. 
trycznej. Zbieżność obydwu części jawi się w umyśle, mimo że postrzeganie donosi o rozbieżności. Doskonały przykład spójności, posiadającej przeczącą jej alternatywę. Ukazujący się naoczności obraz sprawia wrażenie ulokowanego na zakrzywionej powierzchni, choć faktycznie konstytuuje go projekcja przestrzenna.

Obydwie formy przedstawienia — anamorfozę i holografię — zdaje się łączyć takie przejawianie się w obrębie percepcji zmysłowej, które polega na transmisji widzenia zmysłowego do widzenia umysłu. Dopiero w nim dokonuje się pełny odbiór. A skoro tak, trzeba zadać sobie Lacanowskie pytanie: „Jeśli zatem spojrzenie jest odwrotnością świadomości, w jaki sposób spróbujemy je sobie wyobrazićc?" w stanie nie stracić orientacji w płynnych relacjach zachodzących między obiektem, jego reprezentacją a postrzeganiem? Obecność innego konstytuuje spojrzenie, nie tyle jednak relacjonując widziane, ile raczej kreując obraz.

W Symulakrach i symulacji Baudrillard kategoryzuje:

Hologram, doskonały obraz i kres wyobrażenia. A raczej żaden już obraz — prawdziwym medium jest tu laser, skupiona i wysubtelniona wiązka światła, która nie jest już światłem widzialnym i refleksyjnym, lecz abstrakcyjnym światłem symulacji ${ }^{5}$.

Ależ jest widzialne! Do oglądania hologramów nie potrzeba bowiem noktowizora. W dosłownym sensie nie jest natomiast refleksyjnym. Przynajmniej nie takim, jak w wypadku anamorfozy - tej, która spełnia się poprzez odbicie. Anamorficzny fantom staje się rozpoznawalnym obrazem za sprawą modelującej go konstrukcji odnajdywanej przez obserwatora we własnym polu wizualnym. Spojrzenie, z natury ruchome, stale zmienia zakres obserwacji. Szukając odpowiedniego optycznego zapośredniczenia, natrafia $\mathrm{w}$ końcu na szyfrującą zasadę odwrotnego użycia perspektywy w strukturze anamorficznej, pozwalającą właściwie uporządkować obraz $\mathrm{w}$ dostępnym obszarze widzenia. $\mathrm{O}$ niełatwym spełnianiu się procesu mediacji, o wizualnych i myślowych subtelnościach refleksyjnej refleksji, a także o przechodzeniu niewidzialnego w widzialne rozmyślał Jacques Lacan, choć jeszcze wnikliwiej zjawisku anamorfozy przyglądał się Jurgis Baltrušaitis.

„W relacji skopicznej obiektu, od którego zależy fantazm podtrzymujący podmiot w jego zasadniczej chwiejności, jest spojrzenie"6 - skonstatował Lacan, zwracając uwagę na to, jak spojrzenie bywa niestabilne, jak objawia się w zmiennych funkcjach: „pulsacyjnej, oślepiającej, rozpostartej”. Podkreślił też, iż „spojrzenie jest odwrotnością świadomości”, co nie znaczy, że jest niezawisłe od pragnienia, zwłaszcza tego, które rodzi się z potrzeby oglądu. Baltrušaitis uzupełnia:

Anamorfoza nie jest odchyleniem od normy, w którym rzeczywistość zostaje ujarzmiona przez wizję umysłu. Jest optyczną sztuczką, w której to, co widzialne, przesłania to, co rzeczywiste. Elementy tego

4 J. Lacan, Anamorfoza i spojrzenie, [w:] Antologia kultury wizualnej, red. J. Kurz, P. Kwiatkowska, T. Zaremba, Warszawa 2012, s. 374.

5 J. Baudrillard, op. cit., s. 133.

6 J. Lacan, op. cit., s. 373. 
systemu są ze sobą przemyślnie powiązane. Perspektywy przyspieszone i spowolnione wstrząsają naturalnym porządkiem, nie niszcząc go. Perspektywa anamorfotyczna unicestwia go tymi samymi środkami, stosowanymi w sposób skrajny ${ }^{7}$.

Tak toczy się intrygująca gra pomiędzy pozorną prawdą a realną fikcją. Wygrywa fikcja, gdyż prawda gubi się w plątaninie jej pozorów.

W Japonii fotografia nazywana jest shashin, co oznacza odbicie prawdy. Bardzo trafne określenie. Nie prawdę bowiem obraz pokazuje, tylko jej złudzenie. Wszak każde odbicie jest wyłącznie cząstkowe, uszczuplając lub wręcz zatajając istotę tego, co zostaje w nim przedstawione. Już zresztą w momencie zapisu zostają popełnione błędy w ujmowaniu prawdy. Doskonałej kalki nie da się wykonać i to niezależnie od rodzaju użytych narzędzi, więc obojętne jest, czy są one mechaniczne, czy komputerowe. Każde z nich przekazuje jedynie namiastkę.

Odbiór w znacznym stopniu określa pragnienie. To ono wpływa na ukształtowanie oglądu. Widzimy na ogół to, co chcemy zobaczyć lub czego się spodziewamy. Dlatego postrzeganie, będąc uzależnione od potrzeby rozumienia, nie jest neutralne. W związku z tym prawdą prawdziwszą od rzeczywistej prawdy okazuje się nieraz fikcja. W końcu niemal wszystko zależy od tego, co i jak potrafimy sobie wyobrazić. Percepcji i pojmowaniu pomaga koncentracja, wzbogacająca nieuprzedzone widzenie. Jeżeli widzenie nie jest skrępowane utrwalonymi wcześniej stereotypami, szeroko otwiera się na zróżnicowane skojarzenia. Pozwala przykładowo zobaczyć na obrazie przestrzeń, której tak naprawdę na nim nie ma - na płaszczyźnie płótna istnieje bowiem tylko konwencjonalne jej przedstawienie. Tak więc imaginowaniu przestrzeni nie musi przeszkadzać zniewolenie postrzegania płaską powierzchnią reprezentacji trójwymiarowej sceny. Siła wyobraźni z łatwością jest w stanie wyrwać przedstawienie z jego umowności.

Czy jednak koniecznie musi się obrazować przestrzeń wypełnioną konkretnymi przedmiotami? Takie przedstawienia dotyczą przecież nie jej samej, lecz tego, co ją niejako definiuje, ukazując wzajemne położenie znajdujących się w niej obiektów. Czy nie wystarczy wolna od jakichkolwiek wskaźników pustka jako taka? Demokryt był bliski prawdy, twierdząc, że „nie istnieje nic oprócz atomów i pustej przestrzeni”, więc może artyści powinni częściej wypowiadać się wyłącznie pustką? Zwłaszcza, iż pojęcie to jest pojemniejsze od zakresu znaczeniowego pustej przestrzeni. Posiada dziesiątki znaczeń i możliwych interpretacji, nie tylko na Dalekim Wschodzie.

Kiedyś poprosiłem Yasu Suzukę w Kioto o wykaligrafowanie ideogramu pustki, który chciałem wykorzystać w jednej ze swoich realizacji. Zapytał: „Jakiej pustki?” i wyjaśnił, że istnieje ich niemała rozmaitość. Sensy nadawane temu pojęciu są liczne, nie tylko dlatego że wywodzą się z różnych tradycji: tybetańskiej, chińskiej czy koreańskiej, lecz także dlatego że może chodzić o pustkę czekającą na wypełnienie, ale też o pustkę niedostępną, absolutną, pustkę otwartą lub nieosiągalną. Problemem jest

\footnotetext{
7 J. Baltrušaitis, Anamorfozy albo Thaumaturgus opticus, przeł. T. Stróżyński, Gdańsk 2009, s. 7.
} 
wyłącznie to, że łatwiej opisać konkretny rodzaj pustki, niż go czytelnie zobrazować, o ile adekwatne do pojęcia przedstawienie byłoby możliwe do pomyślenia.

Nie trzeba jednak wszystkiego obrazować, nieraz wystarczy ujrzeć okiem umysłu samą ideę, mając przy tym świadomość, że myśl to nie reprezentacja, mimo iż wynika na ogół z doświadczenia. Czysta myśl powinna być wolna od narzucającej się konkretności zewnętrznych znaków.

Zupełnie inny pogląd na istotę poznania miał George Berkeley, kojarzony z pojęciem „bytu obserwowanego" i maksymą esse = percipi. Badacz pisał:

Gdyby ludzie odstąpili od posługiwania się słowami w myśleniu, nie byłoby możliwe, by kiedykolwiek popełnili błąd, wyjąwszy błędy rzeczowe. Mam na myśli to, że zdaje się niemożliwe, by mogli stwierdzić z pewnością coś i by w istocie było inaczej, niż twierdzą. Z pewnością nie mogę popełnić błędu w przypadku prostego postrzeżenia. Jak daleko możemy sięgnąć rozumowaniem, nie posługując się znakami, tak daleko sięga wiedza pewna. W rzeczy samej, w przypadku długich wnioskowań dokonywanych przy użyciu znaków, zawieść nas może pamięć ${ }^{8}$.

Podobną opinię mają buddyści, co lapidarnie, ale i jednoznacznie wyraził Daisetz T. Suzuki:

Postrzeganie odgrywa najważniejszą rolę w buddyjskiej epistemologii, gdyż jest podstawą poznania. Poznanie nie jest możliwe bez postrzegania, wszelka wiedza ma swe źródło w postrzeganiu. Poznanie i postrzeganie są więc zazwyczaj połączone w nauce Buddy. Dlatego filozofia buddyjska wskazuje ostatecznie, aby postrzegać rzeczywistość taką, jaką ona jest. Postrzeganie jest doznaniem oświecenia ${ }^{9}$.

Proces relacji ze światem jest z natury rzeczy mocno skomplikowany. Kiedy poszerzamy i wzbogacamy widzenie, więcej jesteśmy w stanie sobie dopowiedzieć, a dopowiadając, odnosimy wrażenie, że więcej w efekcie widzimy. Sama myśl niekoniecznie musi być reprezentacją. Na ogół jest transparentna dla umysłu, zachowując dystans wobec zewnętrznych znaków, a tym samym będąc niezależna od treści postrzeżeń. Dlatego też to, co myślane, kłóci się nieraz z tym, co widziane, które nierzadko lokuje przedstawienie w dosłowności.

Podejścia do pojmowania rzeczywistości w zróżnicowanych formach jej przejawiania się są nierzadko całkowicie odmienne. Jest to zrozumiałe, kiedy rzecz dotyczy sztuki, mniej, gdy odnosi się do nauki. Filozofia poznania wyrosła bowiem z innej tradycji na Zachodzie, a $z$ innej na Dalekim Wschodzie. Odmienność podejścia w obydwu kulturach do wiedzy i towarzyszącej jej refleksji trafnie charakteryzuje Alan W. Watts, który pisze:

Nauka Zachodu umożliwiła zrozumienie przyrody w kategoriach jej symetrii i regularności, rozbijając najbardziej ekscentryczne przejawy na składniki o kształtach regularnych i dających się zmierzyć. W wyniku tego mamy zwyczaj spostrzegać przyrodę i wykorzystywać ją ze względu na "porządek”,

${ }^{8}$ G. Berkeley, Notatki filozoficzne, fragment 693, cyt. za: P. Spryszak, Filozofia percepcji George’a Berkeleya, Kraków 2004, s. 51.

9 D.T. Suzuki, Outlines of Mahayana Buddhism, New York 1963, s. 235, cyt. za: F. Capra, Tao fizyki, przeł. P. Macura, Kraków 1994, s. 47. 
z którego usunięto element spontaniczności. Ale taki porządek to „maja”10, zaś prawdziwa jakość rzeczy nie ma nic wspólnego z czysto pojęciowymi, suchymi „doskonałymi kwadratami, okręgami albo trójkątami” - chyba że przez spontaniczny przypadek. I dlatego też umysł człowieka Zachodu plącze się, gdy uporządkowane pojęcia o Wszechświecie załamują się i gdy najbardziej podstawowe formy zachowań świata fizycznego okazują się posłuszne „zasadzie niepewności”. Taki świat wydaje nam się bezsensowny i nieludzki, ale znajomość form artystycznych Chin i Japonii mogłaby nas doprowadzić do całkowicie nowego spojrzenia na ten świat i jego żywą, a koniec końców nieuniknioną rzeczywistość ${ }^{11}$.

Watts twierdzi dalej, iż „[b]ezcelowe życie stanowi stały wątek sztuki Zen wszelkiego rodzaju, wyrażając wewnętrzny stan »niezdążania donikąd « artysty w bezczasowej chwili"12. Wątpię, czy formuła ta sprawdza się i obecnie - w czasie, gdy ideowy sens i formalny kształt nadaje sztuce zracjonalizowana technologia, szczególnie w Japonii. Wymowną manifestacją nowoczesnej postawy była w 2010 r. wystawa w Tokio, na której młodzi technoartyści pokazali, do czego próbują uparcie zmierzać.

Oglądając wystawę, zastanawiałem się:

Czy sztuka może się obejść bez narzędzi? Może. A nauka? Też. W pierwszym wypadku będzie to sztuka jako teoria, namysł nad sobą samą, czysta konceptualizacja i nieskalana ilustrującym ją przedmiotem idea. W drugim - wysublimowana spekulacja, oddzielony od praxis myślowy teoremat, refleksja meta - zmierzająca do uogólnień filozoficznych.

Czy nauka może się obejść bez sztuki? Absolutnie. A sztuka bez nauki? Poniekąd. Poniekąd dlatego, że chroniczne uzależnienie od coraz bardziej wyspecjalizowanego narzędzia trudne jest jednak do przezwyciężenia. Owo uzależnienie potęgują coraz to nowe wynalazki. Techniczne protezy ręki oraz aparaty zwiększające zakres widzenia oka powodują nie tylko wzbogacenie o nowe doznania umysłu, ale także czynią go niejako bezwolnym. Nierzadko jest tak, że to nie człowiek steruje maszyną, lecz maszyna powoduje nim.

Tego typu myśli przychodziły mi do głowy na wystawie Cyber Arts Japan w tokijskim MOT, na wystawie, na której młodzi artyści nie tylko dali popis sprawności umysłowej, ale i dowód swego poddaństwa wszechmocnej hi-tech. Podziw budziły możliwości, jakie dają wyobraźni instrumenty skonstruowane w laboratoriach badawczych. Zawód sprawiało często trywialne ich wykorzystanie. Część zgromadzonych na wystawie prac swoją wymową nie odbiegała od banalności przekazów zawartych w grach komputerowych. Stojąc przed niejednym obiektem czekającym na zaangażowaną interaktywność widza, odnosiło się wrażenie, że góra urodziła mysz ${ }^{13}$.

Gdzie w tej i jej podobnej twórczości, a także jak spełnia się zen, miłujący paradoksy i opowiadający się za bezcelowością działania, ponadto preferujący „umysł nie-wiem", daleki od wymogów racjonalności?

Kwadraty, okręgi i trójkąty uznaje się w Europie za użyteczne szablony myślowe, gdyż nakładanie ich na badaną przyrodę przynosi wiarygodne rezultaty. Postawę tę ugruntowała filozofia bazująca na racjonalizmie i pragmatyzmie, skutecznie wspo-

10 W filozofii indyjskiej: iluzja, złudzenie, potężna siła tworząca kosmiczną ułudę rzeczywistego bytu świata materialnego.

11 A.W. Watts, Zen w sztuce, „Pismo Literacko-Artystyczne” 1984, nr 2, s. 91 — rozdział z książki: The Way of Zen, New York 1964.

12 Ibidem, s. 92.

13 J. Olek, Infantylna cybermania, „Artluk” 2010, nr 2, s. 13. 
magana przez utrwalone na przestrzeni wieków reguły nauki, doskonale sprawdzające się w praktyce. Ale i w Japonii traktowane jako symbol podstawowe figury geometryczne zostały z czasem docenione - jedna z najsłynniejszych kaligrafii przedstawia kwadrat, trójkąt i koło, zapisane pędzlem ponad dwa wieki temu przez Gibona Sengaia, mistrza zen. Być może był to przejaw zmieniającego się przed laty podejścia, choć niewykluczone, że była to jedynie przypadkowa i czysto formalna zbieżność. Inna kwestia, że również w świecie zachodnim nie brakuje osób, które wątpią w skuteczność działania prowadzonego z użyciem sztywnych systemów. Jedna $\mathrm{z}$ licznych konstatacji na ten temat sprowadza się do radykalnego stwierdzenia, że w wielu wypadkach nauka nie gwarantuje pewności, a matematyka nie jest w stanie ogarnąć pustki. A jednak jakoś sobie radzi, skoro ujmuje we wzory zarówno najmniejsze struktury materii, jak i gigantyczny wszechświat.

Nie zmienia to faktu, że ciągle powracają w rozważaniach, niemogące doczekać się jasnych odpowiedzi, zasadnicze pytania: o istotę, sens, prawdę, pewność sądu - nie tylko w odniesieniu do teorii, lecz także jej weryfikacji dokonującej się w doświadczeniu. Znamienne, że zwłaszcza w obrębie praktyki ma się na ogół do czynienia z mało przekonującą relacją zawiązaną pomiędzy wiedzą pewną a opinią; nierzadkie są wypadki, kiedy episteme i doksa w znacznym stopniu zachodzą na siebie. Stąd liczne uwikłania we wzajemne zależności episteme (pojmowanej jako wiedza teoretyczna) oraz techne (oznaczającej umiejętności praktyczne).

Dla Platona episteme było rozumowo poznawaną wiedzą, dotyczącą prawdziwego świata idei, w odróżnieniu od złudnego świata zmysłowego, czyli doksy. Całkowicie odmiennie podszedł do znaczenia konkretnie ulokowanej wartości poznawczej Berkeley, uznając jej niezaprzeczalną siłę w przypadku postrzeżeń, a wątpiąc w nią, jeśli miałaby wynikać z wyobraźni. Relacje występujące pomiędzy obydwoma pojęciami odmiennie się przedstawiają, gdy odnosi się je do nauki, takiej jak fizyka, a zupełnie inaczej, kiedy rozpatruje się je na obszarze niesfornej sztuki.

Thomas Kuhn, analizujący dogłębnie charakter i przebieg rewolucji naukowych, wyraźnie akcentuje odmienność wymowy uogólnień nakładanych na faktyczne stany rzeczy od ich rzeczywistego status quo: „przyczyny formalne tłumaczą porządek przyrody, przyczyny sprawcze zaś - odchylenie od tego porządku"14. Nie ma więc ścisłej przystawalności teorii, z jej modelującymi rzeczywistość strukturami, do ujmowanego ową teorią terenu.

Michał Heller patrzy na to zagadnienie nieco inaczej. „Współczesna fizyka nigdy nie zdradza swojego formalnego charakteru. Rozumienie świata przez teorie fizyczne jest zawsze rozumieniem strukturalnym"15 - pisze. A jaką postać przybiera rozumienie w obrębie sztuki? Czy rzeczywiście jest jej potrzebne? Czy nie wystarczy samo techne, a jeżeli już coś więcej, to tylko przypisana zaistniałym postaciom artystycznej

14 T. Kuhn, Dwa bieguny, przeł. S. Amsterdamski, Warszawa 1985, s. 61.

15 M. Heller, Filozofia i wszechświat, Kraków 2008, s. 353. 
wypowiedzi podatna na zmiany doksa - wachlarz zmiennych opinii, nieocenionych, gdy są sofizmatami.

Jednoznacznych odpowiedzi na zasadnicze pytania nie ma. Ale też ich być nie może, ponieważ stosowane metody badawcze, mające pełnić rolę narzędzi pomocnych w poznawaniu świata, mają wpisane w siebie istotne ograniczenia, czego przykładem w matematyce jest niezupełność arytmetyki, a w logice - twierdzenia limitacyjne. Niedoskonałości te udowodnili ponad wszelką wątpliwość tacy uczeni, jak Alfred Tarski (twierdzenie o niedefiniowalności prawdy), Kurt Gödel (twierdzenie o niezupełności) i Alonzo Church (twierdzenie o nierozstrzygalności rachunku predykatów).

Zachwiało to podstawami matematyki i jej filozofii. Uświadomiło, że istnieją problemy nierozstrzygalne. Każda próba ich rozwiązania prowadzi do paradoksu. Choć są wśród nich i wielce obiecujące, takie choćby, jak paradoks Banacha-Tarskiego z 1924 r., który umożliwia podwojenie stanu posiadania — zrobienie z jednej kuli dwóch identycznych kul. Metoda wydaje się prosta. Kulę należy pociąć na skończoną liczbę części, a następnie stosując obroty i translacje, złożyć z otrzymanych elementów dwie kule o identycznym promieniu jak wyjściowa. Niby proste, choć niewykonalne w świecie rzeczywistym. Gdyby było realne, cudowne rozmnażanie stałoby się chlebem powszednim. Łatwo wyobrazić sobie, jak łapczywie korzystaliby z tej możliwości nienasyceni w ekspresji artyści. Na szczęście teoria mnogości nie ma prostego przełożenia na materię sztuki. Kant uważał, iż „w każdym poznaniu tyle tylko jest prawdy, ile jest w nim matematyki”. Kiedy jednak to było...

Pozostaje zaufać mocy sprawczej paradoksów. W końcu sztuka żywi się nimi skutecznie od wieków, nieustannie rozbudowując eklektyczny gmach własnych osiągnięć: dalece niestabilny monument, tworzony z tysięcy wzajemnie wykluczających się, świadomie formułowanych antynomii.

Ale i w badanej przez naukę naturze nie brakuje sprzeczności. Wystarczy przypomnieć, że nawet światło zmaga się ze swoją dwojakością. Ujawniając swą falowość, trzyma w zanadrzu korpuskularność, i odwrotnie, zdecydowanie nie chcąc się jednoznacznie określić. To jeszcze jeden symptom niepewności, z jaką na każdym kroku mamy do czynienia; to wymowna egzemplifikacja nieustającego przebywania w strefie pomiędzy czynionymi ustaleniami i ich nieuchronnymi zaprzeczeniami; to stałe pozostawanie na drodze poznania w obrębie takich przeciwieństw, jak: skończoność-nieskończoność, stałość-zmienność, konieczność-przypadkowość, prostota-złożoność.

Proste figury geometryczne, jednoznacznie zdefiniowane w matematyce, obrosły w zmieniającej się kulturze w liczne znaczenia. Kwadrat dla przykładu oznacza Absolut, doskonałość boską, Objawienie, niebieskie Jeruzalem, cztery pierwiastki świata, wszechświat, ziemię, przestrzeń, cztery strony świata, cztery części, jednolitość, porządek, solidność, zakotwiczenie, stagnację, nieruchomość, ciało, cztery okresy życia ludzkiego, wiedzę, sprawiedliwość, bezstronność, prostotę, wytrwałość czy honor. 
Wprowadzony jako znak do malarstwa ma w indywidualnych praktykach artystycznych zdecydowanie węższy zakres znaczeniowy. Dla Kazimierza Malewicza wywołujący odczucie bezprzedmiotości Czarny kwadrat na białym tle był w pewnej mierze zagadką; dla Josefa Albersa eksperymenty z serii Hołd dla kwadratu były optyczną grą sugerującą trójwymiarowość obrazu, uzyskiwaną przez odpowiednie zestawienie kolorów sąsiadujących z sobą kwadratów - ulokowanych jeden na drugim czy raczej jeden w drugim; dla Marka Rothki Pomarańczowy i Czerwony na Czerwonym stanowił - jak wiele innych jego obrazów wyrażających w czystej formie różne postaci ludzkiego doświadczenia - manifestację emocjonalnego aspektu kolorów działających wielkimi płaszczyznami; u Sola LeWitta kwadrat i sześcian stały się modułami służącymi do budowania rozmaitych dwu- i trójwymiarowych struktur w rodzaju Niepetnych otwartych sześcianów; z kolei u Ryszarda Winiarskiego Czarny kwadrat, czyli fruwająca geometria stanowił grupę wieloboków zestawionych z fragmentów pociętych na części kwadratów. Ale i tak wszystko to, co kwadraty dla artystów znaczyły, i czym wraz z upływem lat piętrowo obrosły, jest czysto umowne. Siła wyrazu wymienionych tu dzieł nie zależy bowiem od naddanego im sensu. Wymowne są same w sobie - regularną formą i wypełniającym ją kolorem. Parafrazując maksymę Czuang-tsy: „słowa istnieją po to, aby wyrazić pojęcia, gdy się wyrazi pojęcia, nie myśli się o słowach", należałoby stwierdzić, że idee dodane do obrazów ukierunkowują odbiór, kiedy jednak człowiek znajdzie się w bezpośrednim kontakcie z dziełem, nic poza jego walorem wizualnym nie jest potrzebne.

Odbiorca postrzegający obraz jest jak elektron związany siłą wzajemnego oddziaływania $\mathrm{z}$ jądrem atomu. Jądro od jego satelity dzieli olbrzymia odległość, niewypełniona niczym materialnym, co by je spajało. Podobnie obraz nie potrzebuje pośrednictwa autorskiej idei czy krytycznej interpretacji, aby przyciągnąć uwagę widza. Sam z siebie jest w stanie wzbogacić patrzącego o doświadczenie mistyczne. Choć bywa i tak, że wszystko, co obraz swym upostaciowaniem niesie, rozpływa się w nicości. Następuje wówczas oczyszczenie z zapożyczonej wiedzy, czemu sprzyja wolny od świadomości kontakt wzrokowy. Zdają się to potwierdzać ustalenia kanadyjskich naukowców Melvyna Goodale’a i Davida Milnera, według których istnieją niezależne od siebie świadome i nieświadome procesy widzenia, przebiegające $w$ dwóch różnych mózgach wzrokowych, przetwarzających w odmiennych celach docierające do nich informacje ${ }^{16}$. Dla odbioru sztuki mogłoby to oznaczać dwutorowość percepcji artefaktów, co pozwala snuć rozważania o wolnym od świadomości doznawaniu wrażeń. Kłóci się to z intuicją? Owszem, ale podbudowuje nadzieję na uniezależnienie się od poznawczej konwencji uformowanej przez tradycję.

Obcując z obrazem, z natury autotelicznym, doskonale można obejść się bez słów, albowiem niezbywalną wartością jest samo jego istnienie. Rozbudowana interpretacja bywa po prostu zbędna, na co zwrócił uwagę Julian Przyboś:

16 D.A. Milner, M.A. Goodale, Mózg wzrokowy w działaniu, przeł. G. Króliczak, Warszawa 2008. 
Tkwi jakiś fałsz, jakiś nieuchronny błąd w każdym opisie. Jak w świecie fizyki kwantowej uwzględnia się niepewność wynikającą ze stosunku między tym, co mierzymy, a sposobem mierzenia, tak w opisie jątrzy i niecierpliwi zniekształcające działanie słów, gdy jedno - momentalne - powinno spełnić opisywane zjawisko. W jednym błysku, tak jak w nagłym rozwarciu oczu — winno ukazać, objawić cały krajobraz ${ }^{17}$.

\section{Representation in a reflection}

Summary

Referring to a broad philosophical and cultural background, the author of the paper examines anthropological contexts of seeing and perceiving works, including photographic works. He presents numerous approaches to comprehending reality in the various forms of its manifestation, forms that are often completely different. This is understandable, when we are dealing with art, less so, when we are dealing with science. In addition, the author takes into account the fact that the philosophy of cognition emerged from a different tradition in the West and different in the Far East. The paper is an attempt to organise and explain these categories.

17 J. Przyboś, Z linij widnokręgu, [w:], idem, Linia i gwar, t. 2, Kraków 1959, s. 323 - wiersz napisany w Kudowie w sierpniu 1946 r. 